\title{
Malignant mesothelioma: new insights into tumour biology and immunology as a basis for new treatment approaches
}

\author{
J W Upham, M J Garlepp, A W Musk, B W S Robinson
}

Recent decades have witnessed a dramatic rise in the incidence of malignant mesothelioma as a result of the mining of asbestos and its widespread use in industry. In spite of current measures to reduce exposure to asbestos, the incidence of mesothelioma is predicted to continue increasing for another 20 years $^{1}$ as a result of the prolonged latency period between exposure to asbestos and development of the disease. Given the failure of conventional medical treatment to make an impact on mesothelioma, the need is urgent to develop new treatment strategies directed at this tumour. This review focuses on new insights into the basic tumour biology and immunology of mesothelioma, and suggests how they might be applied in new approaches to treatment.

Ineffectiveness of conventional treatment Regardless of the modality used, conventional forms of treatment for mesothelioma have proved disappointing. ${ }^{2}$ There is no clear evidence from the literature that surgery improves the survival of patients with this disease. ${ }^{3}$ Even though a small number of patients with early disease appear to enjoy prolonged survival following resection, it is unclear whether this is due to the surgery itself or is simply a reflection of patient selection. Despite claims that aggressive procedures such as extrapleural pleuropneumonectomy may be beneficial, the operative mortality is significant and no clear survival advantage has been shown, compared with supportive care only. ${ }^{4}$ Furthermore, the tumour is unresectable at presentation in the majority of patients. ${ }^{4}$ Surgery such as pleurectomy or surgical pleurodesis occasionally has a place in the palliation of refractory pleural effusion.

Radiotherapy to pleural lesions is generally ineffective as the tumour is radioresistant. Even when used for palliation of severe local pain or superior vena caval obstruction responses are infrequent ${ }^{356}$ and may be associated with significant pulmonary toxicity. Intracavitary radiotherapy in various forms has also proved to be largely ineffective. ${ }^{3}$

Chemotherapy has also proved to be of limited value in this disease. ${ }^{7} \mathrm{~A}$ recent review of the literature on single agent chemotherapy noted an average response rate of only $13 \%$ in 21 trials covering 552 patients. ${ }^{8}$ Some of the more active agents include doxorubicin, cisplatin, and high dose methotrexate. ${ }^{9-12}$ Unfortunately, mesothelioma frequently exhibits primary and secondary drug resistance to currently available chemotherapeutic agents. ${ }^{13-15}$ If methods can be developed to inactivate tumour drug resistance genes, the role of chemotherapy may expand in the future.

In view of the relative ineffectiveness of current approaches it appears that advances in the treatment of mesothelioma are unlikely to follow from refinements of current treatments. Rather, improved understanding of the basic biology of mesothelioma and the host immune response to the tumour is required to provide a rational platform from which new approaches can be developed.

\section{Pathogenesis of mesothelioma}

The development of animal models of the disease $^{16-18}$ and human and rodent cell lines ${ }^{17-23}$ has provided the opportunity to investigate the roles of growth factors and their receptors, cytokines, oncogenes, and tumour suppressor genes in the development and proliferation of mesothelioma. Several growth factors have been reported to be expressed by mesothelioma cells lines. These include platelet derived growth factors (PDGF) A and B, insulin-like growth factors (IGF) I and II, transforming growth factor (TGF) $\alpha$ and $\beta,{ }^{2023-27}$ as well as other less well defined mitogenic products. ${ }^{28}$

Although each of the growth factors listed above has the capacity to act in an autocrine manner to enhance tumour growth, and although mRNA encoding the receptors for each has been described in human and rodent mesothelioma cell lines, ${ }^{242529}$ there is little direct evidence that they play a part in tumour development and progression. The transfection and expression of the gene for PDGF-A in a transformed but non-malignant mesothelial cell line has been shown in one study, however, to confer a malignant phenotype, ${ }^{30}$ and antisense oligonucleotides to PDGF-A can inhibit proliferation of mesothelioma cell lines in vitro. $^{2425} \mathrm{~A}$ role for PDGF-B has also been suggested based upon the expression of PDGF- 
B mRNA ${ }^{202324}$ and the upregulation of expression of the PDGF-B receptor in mesothelioma cell lines and primary tumours. ${ }^{31-33}$ Further support comes from recent experiments in which the transfection and expression of a hammerhead ribozyme against PDGF-B mRNA decreased mesothelioma cell growth in parallel with a decrease in PDGFB expression. ${ }^{34}$ Hence, a possible therapeutic approach is the use of this type of technology to inhibit the synthesis of an autocrine agent. The effect of the induction of antisense RNA after transfection of antisense constructs into mesothelioma cell lines is currently being evaluated by a number of laboratories.

ONCOGENES AND TUMOUR SUPPRESSOR GENES Analysis of mesotheliomas for the presence of common mutations in oncogenes or tumour suppressor genes offers the potential to identify key cellular mechanisms responsible for uncontrolled cell growth such that these can be targeted therapeutically. To our knowledge no mutations in the known oncogenes have yet been described in mesothelioma. Similarly, the analysis of mutations in tumour suppressor genes has not revealed consistent variations specific to mesothelioma, though the role of $p 53$ remains to be clarified. Mutations of the p53 gene are present in a significant proportion of murine asbestos-induced mesothelioma cell lines ${ }^{17}$ but have been detected in only a minority of cases of human mesothelioma, ${ }^{356}$ although p53 protein is often readily detectable in tumour samples by immunocytochemistry. ${ }^{37} 38$ The retinoblastoma gene appeared to be expressed normally in a series of human mesothelioma cell lines ${ }^{39}$ although analysis of primary tumours by immunocytochemistry using monoclonal antibodies reactive with two different epitopes of the retinoblastoma gene product revealed differing reaction patterns in neoplastic and non-neoplastic mesothelial cells. ${ }^{40}$ This observation requires confirmation. The recent demonstration of a very high frequency $(85 \%)$ of homozygous deletions of the $p 16$ gene in a series of mesothelioma cell lines, together with homozygous deletion of $p 16$ in $22 \%$ of primary tumours ${ }^{41}$ and the frequent demonstrations of aberrations of chromosome $9 \mathrm{p} 21 \mathrm{p} 22$, suggest that either $p 16$ or other tumour suppressor genes in this area may be involved in the pathogenesis of mesothelioma. ${ }^{4142}$

The WT-1 gene, a tumour suppressor gene which is often mutated in Wilms' tumour, is expressed in the mesothelium during embryogenesis and at least one isoform is capable of interacting with the promoters of IGF-II and PDGF-A. ${ }^{43}$ Expression of this gene has been detected in the majority of both mesothelioma and normal mesothelial cell lines ${ }^{43}$ (Versnel, personal communication). DNA sequence analysis of the $W T-1$ gene in many samples of mesothelioma or mesothelioma cell lines has revealed only one aberration, a homozygous point mutation not present in the germline DNA, in an unusual peritoneal multicystic tumour which may not have been associated with asbestos exposure. ${ }^{44}$ Interestingly, there are at least four reported cases of pleural mesothelioma occurring in patients who have been cured of Wilms' tumour during childhood. ${ }^{445}$ These data raise the interesting possibility of heterogeneity in the genetics of mesothelioma development, with $W T-1$ mutation being rare in asbestos-related disease but being associated with other forms of the disease. ${ }^{44}$

\section{Immunology of mesothelioma}

An ideal approach to the treatment of mesothelioma would be to enlist the host's immune system to eradicate the tumour. Some data suggest that this may be feasible. The immunologically relevant cytokines interferon alpha (INF $\alpha$ ), interferon gamma (INF $\gamma$ ), and tumour necrosis factor alpha (TNF $\alpha$ ) can directly inhibit the growth of a proportion of human mesothelioma cell lines in vitro. ${ }^{14224647}$ In the murine model of asbestos-induced mesothelioma a hybrid interferon $\alpha / \beta$ significantly delayed tumour development in vivo despite the absence of any significant direct effect of this cytokine on in vitro tumour growth ${ }^{48}$ suggesting in vivo recruitment of the immune system.

Mesothelioma cells can be killed directly by lymphoid effector mechanisms. Both human and murine mesothelioma cell lines are susceptible to non-MHC restricted lysis in vitro by lymphokine activated killer (LAK) cells, and by certain gamma-delta $\mathrm{T}$ lymphocytes, but not to natural killer (NK) cell lysis. ${ }^{46495}$ The susceptibility to lysis is not altered by prior exposure of the mesothelioma cells to either INF $\gamma$ or INF $\alpha .{ }^{46}$ Overall, these studies suggest that mesothelioma cells are susceptible to destruction by immunological means. The challenge is to develop immunotherapeutic approaches which will be effective against mesothelioma in humans.

The ability of tumour cells to engender an immune response or to act as targets for antigen-specific immune effector cells is, in part, determined by the cell surface antigens and the soluble factors released by those cells. Both human and murine mesothelioma cell lines constitutively express abundant cell membrane class I MHC molecules, and this expression can be upregulated by treatment with either INF $\gamma$ or INF $\alpha .{ }^{1646}$ In contrast, mesothelioma cell lines constitutively express little or no class II MHC molecules, though INF $\gamma$ can upregulate class II expression in some cell lines. Thus, although mesothelioma cells bear the class I MHC molecules necessary for engagement of cytotoxic CD8 $+\mathrm{T}$ cells, their ability to activate CD4 $+\mathrm{T}$ cells is questionable and this may contribute to the ability of this tumour to escape immune surveillance (as discussed further below). Vaccination with irradiated cells from at least one murine mesothelioma cell line can, however, prevent the subsequent growth of unirradiated tumour cells in mice, suggesting that mesothelioma tumour antigens are present in this line.$^{21}$ Further, transfection of the gene for the B7-1 costimulatory molecule into mesothelioma lines can result in slowing of in vivo growth. As $T$ 
cell activation requires the presence of $\mathrm{MHC}$, B7-1 and antigen, these data imply that mesothelioma antigens are present, although they have not yet been identified. This supports the notion that the MHC molecules are presenting potentially immunogenic peptides (see below).

IMMUNE EVASION BY MESOTHELIOMA CELLS Recent data derived from an animal model of mesothelioma suggest that the tumour does induce an immune response in the host, but that this response is rendered ineffective within the tumour milieu by products of mesothelioma cells ${ }^{51}$ in a situation analogous to that observed in other tumour systems. ${ }^{52}$ Analysis of tumour infiltrating lymphocytes has shown a downregulation of certain lymphocyte surface markers, particularly CD2 and CD $3 .^{51}$ In addition, preliminary evidence suggests that mRNA for some subunits of the CD3 complex is selectively reduced in tumour infiltrating lymphocytes, and that this may be indicative of functional inactivation of these cells in the tumour microenvironment. ${ }^{53}$ Similarly, tumour infiltrating macrophages exhibit reduced expression of MHC class II and adhesion molecules which may also contribute to the ability of mesothelioma to escape the host immune response. ${ }^{51}$ Notwithstanding the difficulties of performing similar studies in humans, it will be of great interest to examine tumour infiltrating lymphocytes and macrophages in human mesothelioma.

It appears that soluble factors secreted by mesothelioma cells may be responsible for some of the effects described above. Two of the most relevant to the development of an antitumour response are TGF- $\beta$ and interleukin 6 (IL$6)$. TGF- $\beta$ is a powerful immunosuppressant, capable of inhibiting $T$ cell responses. As the majority of mesothelioma cell lines express and secrete various isoforms of TGF- $\beta$, often at high levels, ${ }^{2327}$ it has been proposed that TGF$\beta$ secreted by the tumour may act locally to inhibit the activity of $T$ cells and therefore contribute to immune evasion in mesothelioma. This is supported by the observation that in vivo suppression of tumour TGF- $\beta$ release by stable transfection with an inducible TGF- $\beta$ antisense construct is associated with increased tumour $T$ cell numbers and expression of $\mathrm{T}$ cell surface markers. ${ }^{27}$ These observations concerning TGF- $\beta$ will need to be taken into consideration in the development of strategies designed to enhance the immune response to mesothelioma.

A second immunologically relevant cytokine produced by the majority of the mesothelioma cell lines is IL-6. ${ }^{54}$ This pleiotropic cytokine has pro-inflammatory, immunoregulatory, and haemopoietic effects. Its role in the pathogenesis of mesothelioma remains to be defined, but a role in the development of thrombocytosis associated with the disease has been postulated. ${ }^{54}$ Data derived from this laboratory suggest that IL-6 may also play a central part in the development of systemic clinical features associated with mesothelioma development since in vivo inhibition of IL-6 inhibits the development of cachectic signs in mice, but does not prevent tumour growth. ${ }^{48}$ This interesting observation suggests that blockade of IL-6 in mesothelioma patients may improve their quality of life substantially. The relative contributions of the tumour and the immune response to circulating IL-6 in this system remain to be clarified. The expression of other cytokines, such as granulocyte-macrophage colony stimulating factors (GM-CSF) and MCSF, by mesothelioma cell lines has also been reported. ${ }^{5455}$ Their relevance to tumour progression and any part they may play in the development of antitumour responses are unknown.

\section{ENHANCING THE IMMUNE RESPONSE TO}

MESOTHELIOMA BY GENE TRANSFER

One approach to enhancing the usually weak immune response to the presence of mesothelioma is to use gene transfer techniques to alter mesothelioma cells so that they are more immunogenic. Protocols used in other experimental and human cancers ${ }^{56}$ have included the transfection and expression of genes for various cytokines, allogeneic or syngeneic MHC molecules, foreign antigens, and costimulatory molecules. ${ }^{56-58}$ The aim of such experiments is not just to achieve rejection of transfected tumour cells but, more importantly, to induce a concomitant immune response which is effective against the parental untransfected tumour cell line. The ultimate aim of such an approach in human disease is that transfection of only a small proportion of a patient's mesothelioma cells will be sufficient to produce an immune response effective against the whole of the tumour. Transfection of allogeneic class I MHC molecules has proven effective in other experimental systems ${ }^{57}$ and is currently undergoing clinical trial in melanoma. ${ }^{58}$ In a murine model mesothelioma cell lines transfected with allogeneic MHC were universally rejected, but immunity was not induced to the parental cell line. ${ }^{59}$ The expression of syngeneic class II genes in this cell line was also insufficient to confer protective immunity (Leong et al, unpublished observations).

In order to generate an effective immune response an antigen presenting cell must not only express MHC molecules and antigens, but must also provide a "second signal" to $T$ cells before they will respond. The key group of these critical co-stimulatory molecules are the recently defined $\mathrm{B} 7-1, \mathrm{~B} 7-2$ and $\mathrm{B} 7-3$ molecules. ${ }^{60}$ In some systems the expression of B7-1 by the transfectant tumour lines has induced a protective immunity against the parental tumour, although the effectiveness of this approach may depend on the inherent immunogenicity of the tumour cell being examined. ${ }^{6162}$ In recent work from our own group a poorly immunogenic murine mesothelioma cell line was genetically engineered to express murine B7-1, and a series of B7-1 expressing clones was derived. When compared with the parental cell line, several of these transfectant clones were markedly retarded in their in vivo growth. Inoculation of these trans- 
fectants induced tumour-specific cytotoxic $T$ cells (Leong et al, unpublished observations). Despite similar levels of B7-1 expression there was some heterogeneity in in vivo growth rates between clones, suggesting that co-stimulatory molecule expression alone was not sufficient to ensure tumour rejection.

Taken together these experiments suggest that, even though mesothelioma cell lines are poorly immunogenic, their growth can be inhibited or they can be lysed by cells of the immune system if appropriate co-stimulation is provided and/or if a sufficiently strong tumour antigen is expressed. The recent observation of SV40-like virus sequences in some human mesothelioma samples, and the demonstration that many of these patients had circulating antibodies to SV40 antigens, ${ }^{63}$ raises the possibility that the immune system may respond to tumour-specific antigens in mesothelioma, and that an effective antitumour response may be generated if this response can be upregulated and modulated to one in which cytotoxic immunity predominates. This modulation might be achieved using the approaches described above, either alone or in combination with the transfer and expression of cytokine genes, to produce tumour-specific immunotherapy.

CLINICAL STUDIES OF BIOLOGICAL RESPONSE MODIFIERS IN MESOTHELIOMA TREATMENT Interferons have been examined in preliminary clinical studies in view of their capacity to directly inhibit tumour cell growth and to upregulate expression of MHC class I molecules on the surface of mesothelioma cells. ${ }^{46} \mathrm{Sig}$ nificant reductions in tumour bulk were observed in $16 \%$ of patients enrolled in a phase II study of recombinant INF $\alpha 2$ a administered systemically. ${ }^{64}$ In a subsequent study the addition of doxorubicin to $\mathrm{INF} \alpha$ increased toxicity without improving the rate of response. ${ }^{65}$ Von Hoff et al reported no responses to INF $\beta .^{66}$ More promising was an evaluation of intrapleural INF $\gamma$ in mesothelioma ${ }^{67}$ where responses were observed in approximately one third of patients, although complete responses occurred only in subjects with tumour nodules of less than $5 \mathrm{~mm}$ diameter at pleuroscopy. Taken together, these few studies suggest that some of the interferons are active in a minority of patients and provide further encouragement that immune stimulation may be useful in mesothelioma.

Another cytokine which has been studied is IL-2, a factor which can augment T cell, NK cell, and LAK cell activity against different types of tumours. When administered intrapleurally with autologous LAK cells to patients with mesothelioma, IL-2 produced substantial local and systemic side effects which precluded its further use in clinical trials, ${ }^{68}$ at least using the intrapleural route of administration.

We have recently commenced clinical trials using cytokines delivered directly into the tumour. The rationale for this approach is that cytokines, particularly lymphokines, tend to act locally within tissue microenvironments, rather than systemically, so delivery into the tumour should stimulate a local immune response with reduced systemic side effects. Our preliminary results delivering recombinant INF $\alpha 2 \mathrm{~b}$ or GM-CSF continuously into the tumour indicate that this approach is feasible and is associated with fewer side effects than systemic therapy, but it is too early in the study to determine if local and/or distal tumour reduction occurs

\section{Other recent developments in mesothelioma therapy}

Several other novel therapeutic strategies have been tried recently in patients with mesothelioma.

\section{PHOTODYNAMIC THERAPY}

This involves the administration of a photosensitiser porphyrin molecule followed by direct intracavity photodynamic therapy aimed at destroying the porphyrin-containing tumour cells. This approach has been used at a number of centres and has been shown to be reasonably well tolerated with modest success, mostly in good risk patients with low tumour burdens, often following resection. ${ }^{69-71}$

\section{IMMUNOCONJUGATE THERAPY}

The use of monoclonal antibodies with specificity for tumours, usually conjugated to a toxin (such as ricin) or a radioactive particle, has been considered for patients with mesothelioma. This idea has some laboratory data to support the concept, in that human mesothelioma cells growing intraperitoneally in immunodeficient nude mice could be successfully destroyed by a ricin A-antitransferrin receptor antibody conjugate given intraperitoneally 24 hours after tumour administration. ${ }^{72}$ Clinical trials have not been reported, however, due to the absence of a mesothelioma-specific target molecule.

\section{CHEMOHYPERTHERMIA}

Chemohyperthermia represents a combination of intracavity chemotherapy with intracavity hyperthermia. Only a few patients have been studied and it is not possible to evaluate results. $^{73}$

\section{Future prospects}

Mesothelioma is proving to be an important target disease for evaluating new approaches to cancer treatment such as gene therapy. This is because it is extremely resistant to conventional therapy, is "accessible" for delivery of agents and, importantly, there is a suitable animal model of the disease which permits preclinical laboratory screening of potential therapies.

Several gene therapy protocols for mesothelioma are currently being developed in a number of centres. Genes for cytokines, immune recognition, and tumour suppressor 
Novel approaches to treatment of mesothelioma

\begin{tabular}{|c|c|c|}
\hline Novel approach & Principle of action & Potential problems \\
\hline $\begin{array}{l}\text { Antisense to PDGF A or B } \\
\text { Antisense to TGF- } \beta\end{array}$ & $\begin{array}{l}\text { Inhibition of autocrine growth factor } \\
\text { Inhibits growth promoting properties } \\
\text { Prevents immunosuppressive effects }\end{array}$ & $\begin{array}{l}\text { Need to transfect virtually all tumour cells } \\
\text { Need for extensive transfection }\end{array}$ \\
\hline Transduction of native $p 53$ gene & Restoration of $p 53$ function & $\begin{array}{l}\text { Need to transfect all tumour cells } \\
\text { Not all mesotheliomas have } p 53 \text { mutations }\end{array}$ \\
\hline $\begin{array}{l}\text { Intratumoral cytokines } \\
\text { (by infusion or gene transfer) }\end{array}$ & $\begin{array}{l}\text { Increased immune response in the tumour leads } \\
\text { to strong systemic immunity }\end{array}$ & $\begin{array}{l}\text { Inability to destroy large tumour loads or } \\
\text { secondary deposits }\end{array}$ \\
\hline Gene therapy with B7 molecules & Induction of a strong antitumour response & Potential for induction of autoimmune disease \\
\hline $\begin{array}{l}\text { Gene therapy with thymidine kinase "suicide" } \\
\text { gene and gancyclovir }\end{array}$ & $\begin{array}{l}\text { Uptake in a cavity with widespread tumour } \\
\text { destruction }\end{array}$ & Unlikely to eradicate $100 \%$ of tumour cells \\
\hline Photodynamic therapy & $\begin{array}{l}\text { Uptake of porphyrin followed by lysis with } \\
\text { phototherapy }\end{array}$ & $\begin{array}{l}\text { Time consuming. Limited ability to destroy all } \\
\text { tumour cells }\end{array}$ \\
\hline $\begin{array}{l}\text { Immunoconjugate therapy } \\
\text { ( } \pm \text { toxin or radioactive particles) }\end{array}$ & "Magic bullet" destroys mesothelioma cells & No mesothelioma-specific target yet described \\
\hline Gene therapy to inactivate drug resistance genes & Improve sensitivity to chemotherapy & Inability to transfect $100 \%$ of tumour cells \\
\hline
\end{tabular}

molecules are being transferred using liposomal, retroviral and vaccinia delivery systems.

Another novel method undergoing evaluation is the introduction of the herpes simplex virus thymidine kinase gene into mesothelioma ${ }^{74}$ so that the growth of the tumour can then be inhibited with gancyclovir. While there is some evidence for growth inhibition of "bystander" tumour cells, the ultimate success of approaches such as this may depend upon efficient incorporation into a relatively high percentage of tumour cells. If this proves to be the case in mesothelioma, this would appear to limit its use to cases in which the pleural space is not obliterated by adhesions or tumour and where high efficiency and repeated delivery can occur.

Some of the novel approaches to the treatment of mesothelioma are shown in the table. While there remain significant obstacles (including cost) which need to be overcome, the information arising from recent research gives rise to cautious optimism that these new approaches will be successfully applied to the treatment of mesothelioma. Other potentially useful treatments which are currently under study include the development of an anti-mesothelioma vaccine and improved methods of following disease activity. It is hoped that the above immunobiology and immunotherapy studies will lead to the development of an effective tumour vaccine by identifying common tumour antigens and optimal methods of immunostimulation. This is attractive because individuals exposed to large amounts of crocidolite asbestos are at high risk and are identifiable in advance. Although thoracic computed tomographic scanning has dramatically improved our ability to evaluate tumour regression, it is expensive, time consuming, and cannot always differentiate between tumour tissue and non-tumour tissue. Systemic markers of disease (particularly those that can be recognised early in disease) are therefore currently being sought with a particular view to the application of monoclonal antibodies for diagnosis.

Another area of research with potential application to at-risk individuals is the use of cancer preventative agents such as vitamin A and its derivatives, in asbestos-exposed populations at high risk of developing mesothelioma. These agents have direct effects on cell differentiation and immunomodulatory effects which may reduce cancer risk. A large scale study of $\beta$-carotene and retinoic acid in an asbestos-exposed population is currently being undertaken.

\section{Conclusion}

Substantial progress has been made in understanding the biology and immunology of mesothelioma. This has involved laboratory and clinical research by a number of groups throughout the world. It is worthy of mention that these international groups actively collaborate and have formed an International Mesothelioma Interest Group to share information and resources in the hope that the goal of improved diagnosis, treatment, and prevention of the disease can be achieved more rapidly.

1 de Klerk NH, Armstrong BK. The epidemiology of asbestos and mesothelioma. In: Henderson DW et al, eds. Malignant mesothelioma. New York: Hemisphere, 1992: 223-50.

2 Alberts AS, Falkson G, Goedhals L, Vorobiof DA, Van der Merwe CA. Malignant pleural mesothelioma: a disease unaffected by current therapeutic manoeuvres. $f$ Clin Oncol 1988;6:527-35.

3 Musk AW, Bowman RV, Christmas TI, Robinson BWS Management of malignant mesothelioma. In: Henderson DW et al, eds. Malignant mesothelioma. New York: Hemisphere, 1992:292-302.

4 Rusch VW, Piantadosi S, Holmes EC. The role of extrapleural pneumonectomy in malignant pleural mesothelioma. A Lung Cancer Study Group trial. $\mathcal{f}$ Thorac Cardiovasc Surg 1991;102:1-9.

5 Law MR, Hodson ME, Turner-Warwick M. Malignant mesothelioma of the pleura: clinical aspects and sympmesothelioma of the pleura: clinical aspects and symp-

6 Ball DL, Cruickshank DG. The treatment of malignant mesothelioma of the pleura: review of a 5 year experience, with special reference to radiotherapy. Am f Clin Onco 1990;13:4-9.

7 Aisner J, Sigman LM. The role of chemotherapy in the treatment of malignant mesothelioma. In: Antman $\mathrm{K}$ Aisner J eds. Asbestos related malignancy. Orlando: Grune and Stratton, 1987:385-401.

8 Vogelzang NJ. Malignant mesothelioma: diagnostic and management strategies for 1992. Semin Oncol 1992; 19(Suppl 11):64-71.

9 Lerner HJ, Schoenfeld DA, Martin A, Falkson G, Borden E. Malignant mesothelioma: the Eastern Cooperative Oncology Group (ECOG) experience. Cancer 1983;52:19815 .

10 Ardizzoni A, Rosso R, Salvati F, Fusco V, Cinquegrana A De Palma $M$, et al. Activity of doxorubicin and cisplatin combination chemotherapy in patients with diffuse malignant pleural mesothelioma. Cancer 1991;657:2984-7.

11 Markmann M, Cleary S, Pfeifle C, Howell SB. Cisplatin administered by the intracavitary route as treatment for malignant mesothelioma. Cancer 1986;58:18-21.

12 Solheim ØP, Sæter G, Finnanger AM, Stenwig AE. Highdose methotrexate in the treatment of malignant mesothelioma of the pleura. A phase II study. Brf Cancer 1992 65:956-60.

13 Chahinian AP. Laboratory models for the treatment of mesothelioma. In: Antman K, Aisner J, eds. Asbestosrelated malignancy. Orlando, Florida: Grune and Stratton, 1987:375-383.

14 Bowman RV, Manning LS, Davis MR, Robinson BWS. Chemosensitivity and cytokine sensitivity of malignant mesothelioma. Cancer Chemother Pharmacol 1991;28:4206. 
15 Licht T, Fiebig HH, Bross KJ, Hermann F, Berger DP, Shoemaker $\mathrm{R}$ et al. Induction of multiple-drug resistance 1991;49:630-7.

16 Davis MR, Manning LS, Whitaker D, Garlepp MJ, Robinson BWS. Establishment of a murine model of malignant mesothelioma. Int $\mathcal{f}$ Cancer 1992;52:881-6.

17 Cora EM, Kane AB. Alterations in a tumour suppressor gene, p53, in mouse mesotheliomas induced by crocidolite asbestos. Eur Respir Rev 1993;3:148-50.

18 Walker C, Bermudez E, Stewart W, Bonner J, Molloy CJ, Everitt J. Characterisation of platelet derived growth factor and platelet derived growth factor receptor expression in asbestos-induced rat mesothelioma. Cancer Res 1992;52: 301-6.

19 Manning LS, Murch A, Garlepp MJ, Davis MR, Musk AW, Robinson BWS. Establishment and characterisation of five human malignant mesothelioma cell lines derived from pleural effusions. Int 7 Cancer 1990;47:285-90.

20 Versnel MA, Hagemeijer A, Bouts MJH, Van der Kwast TH, Hoggsteden HC. Expression of $c$-sis (PDGF-B chain) and PDGF-A chain genes in ten human malignant mesothelioma cell lines derived from primary and metastatic tumours. Oncogene 1988;2:601-5.

21 Manning LS, Davis MR, Bielefeldt-Ohmann H, Marzo AL, Garlepp MJ, Whitaker D, et al. Evaluation of immunogenicity of murine mesothelioma cells by immunisation. Eur Respir Rev 1993;3:234-7.

22 Zeng L, Buard A, Monnet I, Boutin C, Fleury J, SaintEtienne $\mathrm{L}$, et al. In vitro effects of recombinant human interferon gamma on human mesothelioma cell lines. In $f$ Cancer 1993;55:515-20.

23 Gerwin BJ, Lechner JF, Reddel RR, Roberts AB, Robbins $\mathrm{KC}$, Gabrielson EW, et al. Comparison of production of transforming growth factor-beta and platelet derived growth factor by normal mesothelial cells and mesothelioma cell lines. Cancer Res 1987;47:6180-4.

24 Garlepp MJ, Christmas TI, Manning LS, Mutsaers SE, Dench J, Leong C, et al. The role of platelet-derived growth factor in the growth of human malignant mesothelioma. Eur Respir Rev 1993;3:192-4.

25 Garlepp MJ, Christmas TI, Mutsaers SE, Manning LS Davis MR, Robinson BWS. Platelet-derived growth factor as an autocrine factor in murine malignant mesothelioma. as an autocrine factor in murine

26 Lee TC, Zhang Y, Aston C, Hintz R, Jagirdar J, Perle MA, et al. Normal human mesothelial cells and mesothelioma cell lines express insulin-like growth factor I and associated molecules. Cancer Res 1993;53:2858-64

27 Fitzpatrick DR, Bielefeldt-Ohmann $\mathrm{H}$, Himbeck RP, Jarnicki AG, Marzo AL, Robinson BWS. Transforming growth factor-beta: antisense RNA-mediated inhibition affects anchorage-independent growth, tumorigenicity and tumour-infiltrating T-cells in malignant mesothelioma. Growth Factors 1994;11:29-44.

28 Lauber B, Leuthold M, Schmitter D, Cono-Santos J, Waibel $\mathrm{R}$, Stahel R. An autocrine mitogenic activity produced by a pleural human mesothelioma cell line. Int $f$ Cancer 1991; 50:943-50.

29 Langerak AW, Dirks RPH, Versnel MA. Splicing of the platelet-derived growth factor A chain mRNA in human malignant mesothelioma cell lines and regulation of its expression. Eur F Biochem 1992;2-8:589-96.

30 Van der Meeren A, Seddon MB, Betsholtz CA, Lechner JF, Gerwin BI. Tumorigenic conversion of human mesothelial cells as a consequence of platelet-derived growth factor $\mathrm{A}$ chain. Am $\mathcal{F}$ Respir Cell Mol Biol 1993;8:214-21.

31 Langerak AW, Vietsch H, Bouts MJ, Hagemeijer A, Versnel $\mathrm{MA}$. A spontaneously in vitro transformed mesothelial cell line has a similar pattern of PDGF chain and PDGF receptor expression to malignant

32 Versnel MA, Langerak AW, van der Kwast T, Hoogsteden HC, Hagemeijer A. Expression of PDGF chains and PDGF receptors in human malignant mesothelial cell PDGF receptors in human malignar

33 Ramael M, Buysse C, van den Bossche J, Segers K, van Marck E. Immunoreactivity for the beta chain of the platelet-derived growth factor receptor in malignant mesotheliomas and non-neoplastic mesothelium. F Pathol 1992; 167:1-4.

34 Dorai T, Kobayashi H, Holland JF, Ohnuma T. Modulation of platelet-derived growth factor-beta mRNA expression and cell growth in a human mesothelioma cell line by a hammerhead ribozyme. Mol Pharmacol 1994;46:437-44.

35 Cote RJ, Jhanwar SC, Novick S, Pellicer A. Genetic alterations of the p53 gene are a feature of malignant terations of the p53 gene are a feature
mesothelioma. Cancer Res 1991;51:5410-6.

36 Metcalf RA, Welsh JA, Bennett WP, Seddon MB, Lehman TA, Pelin KA, et al. P53 and Kirsten-ras mutations in
human mesothelioma cell lines. Cancer Res 1992;52:26105 .

37 Mayall FG, Goddard H, Gibbs AR. p53 immunostaining in the distinction between benign and malignant mesothelial proliferations using formal

38 Kafiri G, Thomas DM, Shepherd NA, Krausz T, Lane DP, Hall PA. p53 expression is common in malignan mesothelioma. Histopathology 1992;21:331-4.

39 Van der Meeren A, Seddon MB, Kispert J, Harris CC Gerwin BI. Lack of expression of the retinoblastoma gene is not frequently involved in the genesis of human mesothelioma. Eur Respir Rev 1993;3:177-9.

40 Ramael M, Segers K, Van Marck E. Differential immunohistochemical staining of the retinoblastoma protein with the antibodies $\mathrm{C} 15$ and $1 \mathrm{~F} 8$ in malignant mesothelioma. Pathol Res Pract 1994;190:138-41.

41 Lee WC, Altomare DA, Nobori T, Olopade OI, Buckler AJ, Testa JR. p16 alterations and deletion mapping of 9p21-p22 in malignant mesothelioma. Cancer Res 1994; 54:5547-51

42 Knuutila S, Tiainen M, Tammilehto L, Rautonen J, Pyrhonen S, Mattson $\mathrm{K}$. Cytogenetics of human malignant mesothelioma. Eur Respir Rev 1993;3:25-8.

43 Walker C, Rutten F, Yuan X, Pass H, Mew D, Everitt J. Wilms' tumour suppressor gene expression in rat and human mesothelioma. Cancer Res 1994;54:3101-6.

44 Park S, Schalling M, Bernard A, Maheswaran S, Shipley GC, Roberts D, et al. The Wilms' tumour gene WT1 is expressed in murine mesoderm-derived tissues and mutated in a human mesothelioma. Nature Genet 1993;4: mutated in 20 .

45 Austin MB, Fechner RE, Roggli VL. Pleural malignant mesothelioma following Wilms' tumour. Am $\mathcal{f}$ Clin Pathol 1986;86:227-30.

46 Christmas TI, Manning LS, Davis MR, Robinson BWS, Garlepp MJ. HLA antigen expression and malignant mesothelioma. Am 7 Respir Cell Mol Biol 1991;5:213-20.

47 Hand AM, Husgavel-Pursiainen K, Tammilehto L, Mattson K, Linnainmaa K. Malignant mesothelioma: the antiproliferative effects of cytokine combinations on three human mesothelioma cell lines. Cancer Lett 1993;58:20510.

48 Bielefeldt-Ohmann H, Fitzpatric DR, Marzo AL, Jarnicki AG, Musk AW, Robinson BWS. Potential for interferon$\alpha$-based therapy in mesothelioma: assessment in a murine $\alpha$-based therapy in mesothelioma: assessment in

49 Manning IS, Bowman RV, Darby SB, Robinson BWS Susceptibility of fresh and cultured human malignant mesothelioma cells to lysis by natural killer (NK) and lymphokine-activated killer (LAK) cells. Am Rev Respir Dis 1989;139:1369-74.

50 Mavaddat N, Robinson BWS, Rose AH, Manning LS, Garlepp MJ. An analysis of the relationship between gamma/delta $\mathrm{T}$ cell receptor $\mathrm{V}$ gene usage and nonmajor histocompatibility complex-restricted cytotoxicity. Immunol Cell Biol 1993;71:27-37.

51 Bielefeldt-Ohmann H, Fitzpatrick DR, Marzo AL, Jarnicki AG, Himbeck RP, Davis MR, et al. Patho- and immunobiology of malignant mesothelioma: characterisation
of tumour infiltrating leucocytes and cytokine production in a murine model. Cancer Immunol Immunother 1994;39: in a murine

52 Tada T, Ohzeki S, Utsumi K, Takiuchi H, Muramatsu M, LI Shimizu J, et al. Transforming growth factor-beta induced inhibition of $\mathrm{T}$ cell function. Susceptibility differences in $T$ cells of various phenotypes and functions and its relevance to immunosuppression in the tumour-bearing state. F Immunol 1991;146:1077-82.

53 Jarnicki AG, Fitzpatrick DR, Marzo A, Robinson B, Bielefeldt-Ohmann H. Surface antigen and cytokine profile of tumour infiltrating lymphocytes (TIL) in malignant mesothelioma. F Leuk Biol 1993;54(Suppl): 90 .

54 Schmitter D, Lauber B, Fagg B, Stahel RA. Haemopoietic growth factors secreted by seven human pleural mesothelioma cell lines: interleukin-6 production as a common feature. Int $\mathcal{F}$ Cancer 1992;51:296-301.

55 Demetri GD, Zensie BW, Rheinwald JG, Griffin JD. Expression of colony stimulating factor genes by normal human mesothelial cells and human malignant cell lines in vitro. Blood 1989;74:940-6.

56 Culver KW, Blaese RM. Gene therapy for cancer. Trends in Genetics 1994;10:174-8.

57 Hui KM, Sim T, Foo TT, Oei A. Tumour rejection mediated by transfection with allogeneic class I histocompatibility gene. F Immunol 1989;143:3835-43.

58 Nabel GJ, Nabel E, Yang Z-Y. Direct gene transfer with DNA-liposome complexes in melanoma: expression, biologic activity, and lack of toxicity in humans. Proc Natl Acad Sci USA 1993;90:11301-6.

59 Leong CC, Robinson BWS, Garlepp MJ. The generation of an antitumour immune response to a murine mesothelioma cell line by the transfection of allogeneic MHC genes. Int f Cancer 1994;59:212-6.

60 June $\mathrm{CH}$, Bluestone JA, Nadler LM, Thompson CB. The B7 and CD28 receptor families. Immunol Today 1994;15: 321-32.

61 Townsend SE, Allison JP. Tumor rejection after direct costimulation of CD $8+T$ cells by B7-transfected melanoma cells. Science 1993;259:368-70.

62 Chen L, McGowan P, Ashe S, Johnston J, Li Y, Hellstrom I, et al. Tumor immunogenicity determines the effect of B7 costimulation on T cell-mediated tumor immunity. $\mathcal{f}$ Exp Med 1994;179:523-32.

63 Carbone M, Pass HI, Rizzo P, Marinetta M, Di Muzio M, Mew D, et al. Simian virus 40-like DNA sequences in Mew D, et al. Simian virus 40-like DNA sequences in

64 Christmas TI, Manning LS, Garlepp MJ, Musk AW, Robinson BWS. Effect of Interferon-alpha $2 \mathrm{a}$ on malignant inson BWS. Effect of Interferon-alpha 2a on

65 Upham JW, Musk AW, van Hazel G, Byrne M, Robinson BWS. Interferon alpha and doxorubicin in malignant BWS. Interferon alpha and doxorubicin in
mesothelioma. Aust NZ 7 Med 1993;23:683-7.

66 Von Hoff DD, Metch B, Lucas JG, Balcerzak SP, Grunberg SM, Rivkin SE. Phase II evaluation of recombinant interferon-beta in patients with diffuse mesothelioma: a Southwest Oncology Group study. F Interferon Res 1990; 10:531-4.

67 Boutin C, Viallat JR, Van Zandwijk, Douillard JT, Paillard $\mathrm{JC}$, Guerin JC, et al. Activity of intrapleural recombinant 
gamma-interferon in malignant mesothelioma. Cancer 1991;67:2033-7.

68 Robinson BWS, Manning LS, Bowman RV, Christmas TI Musk AW, Davis MR, et al. The scientific basis for the Musk AW, Davis MR, et al. The scientific basis for the Respir Rev 1993;3:195-8.

69 Takita H, Mang TS, Loewen GM, Antkowiak JG, Raghavan D, Grajek JR, Dougherty TJ. Operation and intracavitar photodynamic therapy for malignant pleural mesothelioma: a phase II study. Ann Thorac Surg 1994;58 995-8.

70 Pass HI, Pogrebniak H. Photodynamic therapy for thoracic manin Surg Oncol 1992:8:217-25.

71 Ris HB, Altermatt HJ, Inderbitzi R, Hess R, Nachbur B, Stewart JC, et al. Photodynamic therapy with chlorine for diffuse malignant mesothelioma: initial clinical results. $\mathrm{Br}$

f Cancer 1991;64:1116-20.
72 Griffin TW, Richardson C, Houston LL, LePage D, Bogden A, Raso V. Antitumour activity of intraperitoneal immunotoxins in a nude mouse model of human malignant mesothelioma. Cancer Res 1987;47:4266-70.

73 Carry PY, Brachet A, Gilly FN, Sayag AC, Petit PY, Rochette $C$, et al. A new device for the treatment of pleural malignancies: intrapleural chemohyperthermia preliminary report. Oncology 1993;50:348-52.

74 Smythe WR, Hwang HC, Amin KM, Eck SL, Davison BL, Wilson JM, et al. Use of recombinant adenovirus to transfer the herpes simplex virus thymidine kinase (HSVtk) gene to thoracic neoplasms: an effective in vitro drug sensitization system. Cancer Res 1994;54:2055-9. 